Debate 2

\title{
Informed dissent: the views of some mothers of severely mentally handicapped young adults
}

\author{
Madeleine Simms Institute for Social Studies in Medical Care, London
}

\section{Author's abstract}

Much of the discussion since the Arthur case has centred round the rights of handicapped infants to medical treatment. Little has centred round the question of how far one person can rightly be required to sacrifice her life for another, when she has not been consulted beforehand. This may be due to the fact that most of the discussants are men, while nearly all the carers are women. This small study attempts to redress this balance by asking mothers who have cared for 20 years, whether they felt it was worthwhile.

'The importance of informed consent for treatment is generally accepted. We should recognise that parents may have a right to informed dissent (1).

In the spring and summer of 1985 I had occasion to interview at some length 15 mothers of 17 severely mentally handicapped young adults aged between 19-25 years. This was a pilot study for a survey within the North East Thames Regional Health Authority on the subject of service provision for this group of the disabled.

The territory in question is large and varied. It breaks down into three fairly distinct environments which might be labelled in a rough and ready manner as 'Inner City Deprived', 'Lower Middle Class Suburban', 'Green Belt Country'.

With the help of the local social education and training centres and the local branches of MENCAP (the Royal Society for Handicapped Children and Adults) I managed to locate 15 mothers, some from each of these three different environments, who had severely mentally handicapped children in the right age group and who were prepared to talk to me. I originally approached 22 mothers. Three failed to respond. One told me her life was 'a mess' but she would contact me again later when she sorted herself out. But she never did so. Three were on holiday or otherwise engaged but were willing in principle to see me, had more time been available for the study.

The 15 mothers I interviewed were aged between 39 and 64 years. Eleven were married, two were widowed,

\section{Key words}

Handicapped infants; rights of handicapped infants; human rights; abortion; infant euthanasia. and one each was divorced and separated. One was a Methodist, one a Roman Catholic, while the rest were Anglican, but one of these was married to a Roman Catholic. At the end of the interviews lasting on average one and a half hours, I asked each mother if she would mind answering two further questions not directly related to the main study. One question was whether, with hindsight, they would have preferred to have had an abortion had this been available to them at the time, and the second question was, what they felt about the issue of severely handicapped newborn infants 'receiving all possible medical treatment to enable them to survive'. I explained that I realised these might be difficult questions to answer and that it was not necessary to do so if they preferred not to.

In fact, virtually all the mothers had strongly held views on these subjects which they seemed eager to communicate, sometimes with great passion. None the less, a few mothers might have felt inhibited on grounds of loyalty to their child from responding in too negative a manner, so it is possible that support for abortion and infant euthanasia may in fact have been slightly understated.

\section{Abortion}

Ten of the 15 mothers said that, with hindsight, they certainly would have had an abortion; four said they would not have done so, and one mother was uncertain. Comments made in the course of answering this question included the following:

'At the time we wanted him to live, preferred that he would, but now realise this was a mistake . . . the strain of caring has been overwhelming . ..'

This mother became accidentally pregnant some years later and then managed to obtain an abortion albeit with difficulty. Her comment on the process of obtaining it that prevailed at that time (fifteen years ago) is worth recording:

'Right degrading it was, having to pretend I was barmy!'

Two other mothers who also said they wished they could have had an abortion, said they might not have held this view at that time: 
'In retrospect I would have preferred to have an abortion - though not at the time as I didn't realise what it all involved then ...'

'I really had no idea what I had let myself in for . . . Now we're imprisoned for life . . . There is no future for us $\ldots$. .

\section{Another mother said:}

'The do-gooders on TV make my blood boil. They have no idea what a child like this involves . . '

One mother qualified her support for abortion by remarking that she would have needed to know that 'the degree of damage was likely to be bad' before she would have agreed to it.

One mother who said she would not have had an abortion, observed that she might well have had one at the time had she been offered one and had she been warned what lay ahead. She was glad with hindsight that this choice had not been open to her because she thought having to cope with the child's disability over twenty years had been 'of positive benefit to the rest of the family' in helping to knit it together. However, she was not in any circumstances prepared to risk a second handicapped child so she and her husband had had no further children. This outlook was partially echoed by the only Roman Catholic mother in the group who remarked:

'The handicapped are a blessing in disguise - at least they don't get involved with drugs, muggings, and that . . '

\section{Severely handicapped newborns}

Consistent with this view, this mother strongly supported the notion of using all medical means to keep severely handicapped infants alive. Only two other mothers out of the 15 agreed with this view, though one qualified it by saying that treatment should stop short of a life-support machine, which should never be used on the newborn. The other qualified it with the observation that such infants should be kept alive only 'if they would be able to enjoy their lives'.

However, most mothers expressed strong opinions about how wrong it was to operate on handicapped babies in order to keep them alive:

'They mustn't be treated as guinea pigs just to make doctors feel clever . . .'

Another echoed this theme:

'Leave well alone - they're not guinea pigs.'

Another, who had two affected children, remarked:

'I believe in mercy killing for those diagnosed at birth, though later on it gets more difficult ...'
She observed that when her first child was born their ciderly general practitioner exclaimed: 'It would be better if the Lord took him'. She was quite taken aback to hear this, but now thinks he was right.

The wife of the Catholic husband, who disagreed with abortion on principle, none the less remarked in the context of newborn handicapped life:

'There's no point in prolonging it . . .'

Another remarked of medical intervention:

'It's not fair on them.'

Another mother who disagreed with abortion nonetheless observed:

'Doctors should be allowed to decide not to treat them.'

This view was implicitly challenged by the mother who said:

'Parents need to take this decision; it's not fair to burden the doctors with it.'

Another mother, who had two handicapped children, said:

'It's a subject I have strong views about, although now they're here, of course, I love them . . .'

Another mother who echoed this latter sentiment said she believed in 'letting them die peacefully'. She added:

'You have to think of their supporters too-no social life, no friends, without a good family, you've had it'.

Another mother said:

'It's awful to keep severely handicapped children alive by operating on them ... I had a Spina Bifida sister who died at birth. My Mum always says how glad she is they couldn't keep those children alive in those days and I agree with this. Some people don't know what they're talking about ...'

\section{Summary}

Ten women of the fifteen interviewed wished with hindsight that they could have had an abortion rather than a severely handicapped infant, and twelve out of ? fifteen thought such infants should be allowed to die in ${ }_{0}^{\circ}$ peace rather than have their lives saved by medical $\frac{\vec{D}}{\mathbb{D}}$ treatment. This is only a pilot study and the numbers are $\frac{?}{+}$ too small to enable us to draw any more general $\stackrel{\mathbb{Q}}{\circ}$ conclusions. It is, however, interesting to note that $\bar{Q}$ successive national opinion polls on abortion over many 8 years have shown that more than two-thirds of the public support legal abortion, and that at the time of the trial of Dr Leonard Arthur, the Derby paediatrician accused of 
killing a handicapped child, a higher proportion than this, more than four-fifths of the public, in a MORI poll published in The Times (2), thought doctors in such cases should not be found guilty of murder.

From these interviews it appears that most of these parents do not look upon a lifetime spent caring for a severely handicapped young adult as time well spent, even though they love their children, have compassion for them, and want to do the best for them that they can. Shepperdson's pioneering study in this field, published in 1983, found that half the parents of the Down's syndrome children in her sample believed that 'not all handicapped children should be kept alive at all costs'. She also noted that 'the most vehement replies in favour of euthanasia came from the mothers of the older children' (3). In their study, Pahl and Quine wrote:

'In an attempt to illuminate the overall reality of caring for these children, parents were asked what they would do if they knew that an expected child would be severely mentally handicapped. Seventy-eight per cent of parents answered that they would want the pregnancy terminated' (4).

There is still great controversy about the status of the fetus and the rights of severely handicapped infants in relation to the rights of their parents. Those who have had twenty years' experience caring for young people classified as severely mentally handicapped, have views that deserve to be heard more than most.

\section{Acknowledgement}

Thanks are due to the North East Thames Regional Health Authority that supported the project of which this study is a part, and to Dr P C Walker for his encouragement.

Madeleine Simms MA MSc is Senior Research Officer at the Institute for Social Studies in Medical Care, 14 South Hill Park, Hampstead, London NW3 2SB.

\section{References}

(1) Campbell A G M, Cusine D J. Commentary 2: Focus: On the death of a baby. Fournal of medical ethics 1981; 7: 15 .

(2) The Times 1981 Nov 10: 3

(3) Shepperdson B. Abortion and euthanasia of Down's syndrome children - the parents' views. Fournal of medical ethics 1983; 9: 152-157.

(4) Pahl J, Quine L. Families with mentally handicapped children. University of Kent, 1984. 